\title{
Histology of the Harderian Gland of Domestic Geese (Anser anser domesticus)
}

\author{
Murat Boydak ${ }^{1}$, Mehmet F. Aydin ${ }^{2}$ \\ ${ }^{1}$ Department of Histology and Embryology, Faculty of Veterinary Medicine, University of Selcuk, \\ Konya, Turkey \\ ${ }^{2}$ Department of Histology and Embryology, Faculty of Veterinary Medicine, University of Harran, \\ Şanliurfa, Turkey
}

Received February 12, 2008

Accepted February 9, 2009

\begin{abstract}
The objective of this investigation was to study morphological aspects of the Harderian, paraorbital, gland in domestic geese. Tissues were obtained from 9 male and 9 female adult domestic geese and processed for light microscopy. Tissue sections were stained with Mallory's trichrome, silver impregnation, methyl green-pyronin, periodic acid Schiff, alcian blue ( $\mathrm{pH} 2.5$ ), alcian blue/periodic acid Schiff ( $\mathrm{pH}$ 2.5) and Sudan black B staining techniques. Results revealed the Harderian gland of domestic geese was covered by a capsule, which contributed trabeculae that divide the organ into lobes and lobules. The glandular epithelium was multilobular, compound tubuloalveolar. The secretion of Harderian gland was mucous and the secretion type was apocrine; the gland emptied to the inner surface of the nicticating membrane by a single duct.
\end{abstract}

Harderian gland, domestic geese, histological, histochemical

The Harderian gland (HG, paraorbital) is a tubulo-alveolar gland located within the orbit on the caudal aspect of the eyeball in animals that posses a nicticating membrane (third eyelid). The fact that the HG is primarily found in terrestrial vertebrates lends support to the traditional view that it evolved with the lachrymal glands and lubricated the nicticating membrane and/or cornea, and secondarily the nasopharynx (Olcese and Wesche 1989). $\mathrm{HG}$ is found together with glandulae palpebrae tertiae superficialis in the palpebra tertia of most of the terrestrial species having nictitating membrane. The HG is also found in amphibians and avian species (fowl, pheasants, turkeys, duck, cardinal); it is found in rudimentary form or is absent in primates, and not found in carnivores (Sakai 1981).

The HG may be compound tubular (Schwarz-Karsten 1937; Paule 1957; Bloom and Fawcett 1975) or compound tubulo-alveolar (Liman and Gülmez 1996; Sabry and Al-Ghaith 2000; Pradidarcheep et al. 2003; Altunay and Kozlu 2004; Marcos and Affanni 2005; Munkeby et al. 2006; Khan et al. 2007; Ortiz et al. 2007), indicating that the gland contains both a branched duct system and tubular alveoli (Bloom and Fawcett 1975; Sakai 1981).

The physiological contributions of the HG are still under investigation. It is known that the secretion of HG plays an important role in lubricating the nictitating membrane and/or the cornea (Sakai 1981; Olcese and Vesche 1989; Payne 1994). Sakai $(1981,1992)$ reported contrasting biochemical and physiological characteristics of the HG have been identified. Among these are sexual dimorphism, photosensitivity, synthesis of hormones, assisting the thermoregulatory behaviours and production of pheromones (Sakai 1981, 1992; Payne 1994). Harderian glands of chickens produce or participate in the transmission of three classes of immunoglobulins ( $\operatorname{IgA}, \operatorname{IgG}$, and IgM) (Ohshima and Hiramatsu 2002), and present macrophages, lymphocytes, granulocytes in the subepithelial layer and lumina of the lobules for the local immunity of the eye orbit (Baba et al. 1990).

Address for correspondence:

Assist. Prof. Dr. Murat Boydak

Selçuk Üniversitesi, Veteriner Fakültesi

Histoloji ve Embriyoloji Anabilim Dali

42031 Konya, Turkey
Phone: +90 3322232637
Fax: +90 3322410063
E-mail: yigitharput@gmail.com ; boydak@selcuk.edu.tr
http://www.vfu.cz/acta-vet/actavet.htm 
There are many investigations of the HG camel (Abou-Elmagd 1992), Mongolian gerbils (Saka and Yohro 1981), domestic fowl (Wight et al. 1971ab), domestic duck (Brobby 1972), fowls, turkeys and ducks (Burns and Maxwell 1979; Maxwell and Burns 1979). However, very few report on the morphology of the HG in domestic geese. The objective of the present investigation was to study the morphological (histology and histochemical) aspects of the HG in domestic geese (Anser anser domesticus).

\section{Materials and Methods}

Animals

The HG samples used in the study were obtained from 18 adult healthy domestic geese of both sexes ( 9 females and 9 males), aged 50 to 52 weeks from the Research and Application Unit of Faculty of Veterinary, University of Selçuk. The tissues used in this study were obtained from geese slaughtered for human consumption. The animals were slaghtered in Research and Application Unit of Faculty of Veterinary, University of Selcuk and they received human care according to the criteria outlined in the "Guide for the Care and Use of Experimental Animals" prepared by the National Academy of Sciences and published by the National Institutes of Health.

Paraffin Sections

The right HG was dissected from the periorbital fascia, fixed in $10 \%$ buffered formalin, and embedded in paraffin blocks. Sections $(6 \mu \mathrm{m})$ were made through the entire gland and stained by trichrome, silver impregnation, methyl green-pyronin, alcian blue $(\mathrm{AB})(\mathrm{pH}=2.5)$ (for acidic mucosubstance staining). To investigate the chemical character $(\mathrm{pH})$ of the secretion material in the gland tissue, periodic acid-Schiff (PAS) reaction was employed to determine neutral mucosubstance and alcian blue/ periodic acid-Schiff (AB/PAS) $(\mathrm{pH}=2.5)$ was used for determining neutral and acidic mucosubstances (Culling et al. 1985).

Cryostat sections

The left $\mathrm{HG}$ was dissected, isolated, and fixed in formal-calcium solution at $+4{ }^{\circ} \mathrm{C}$ for one night. The sections (12 $\mu \mathrm{m})$ taken via cryostat (SleeLondon) and stained with Sudan black B (Culling et al. 1985) for the demonstration of lipoid secretion material. The samples prepared were analyzed under light microscope (Leica DM 2500, Leica Microsytems GmbH, Wetzlar, Germany) and photomicrographs of representative regions were made via a digital camera (DFC 320, Leica Microsytems GmbH, Wetzlar, Germany).

\section{Results}

No evident difference between the male and female domestic geese was observed in the histology of either gland or their duct.

The HG of domestic geese used in this study was covered with a thin capsule. This capsule sends septa into the gland and these septa divide the gland into lobes and lobules (Plate III, Fig. 1). The glands were multilobular tubulo-alveolar and emptied into a wide lumen; the secretion mode was apocrine.

Epithelial cells constituting these glands were high columnar. Cells of the apex of the glandular epithelium were darkly stained and contained serous secretion, while deeper portions of the glandular epithelium were lightly stained and contained mucous secretion. The cells in the neck of the glandular endpiece were mucin-producing and their borders were distinctive. The apical cytoplasm of these cells was relatively more acidic (Plate III, Fig. 2).

A single duct, located centrally and having an irregular lumen, was observed (Plate IV, Fig. 3). The duct epithelium was multi-layered and the cell shape varied. These shapes and positions of the cells were changing throughout the duct. Cells of the basal layer of the main duct were polygonal, while the ones near the lumen were cuboidal. Goblet cells were non-uniformly distributed among these cells. There were crypts along the duct and solitary lymphoid nodules were near the crypts; germinal centers were not evident. Nuclei of myoepithelial cells were observed at the base of the ductal epithelium.

PAS-positive cells were observed throughout the glandular epithelium near the lumen (Plate IV, Fig. 4, arrows) and the goblet cells of the main duct epithelium were PAS-positive. With the Alcian blue (AB) staining at $\mathrm{pH}$ 2.5, AB-positive cells were observed in the glandular units (Plate V, Fig. 5) and the main duct. In combined Alcian blue/periodic acid-Schiff (AB/ PAS) ( $\mathrm{pH} 2.5$ ) staining, there were no differences between the tissue sections in terms of 
positivity. AB/PAS-positive cells were observed in the apex of glandular units (Plate V, Fig. 6 , arrows) and goblet cells of the main duct epithelium as well.

In the silver impregnation staining, reticular fibres were observed in the capsule and septa of the HG. These reticular fibres were extending as far as the apex of glandular unit as thin branches. The reticular fibres located in the septa were thicker and formed a network (Plate VI, Fig. 7). In the methyl green-pyronin staining, plasma cells were observed beneath the capsule and in the septa. The plasma cells were also observed near the crypts of the main duct (Plate VI, Fig. 8). Sudan black B oil staining failed to stain, the HGs of domestic geese of this study.

\section{Discussion}

The HG is a compound tubulo-alveolar gland located within the periorbita of many terrestrial species, especially those possessing a nicticating membrane (Woodhouse and Rhodin 1963; Norvell and Clabough 1972; Olcese and Wesche 1989). Secretory vesicles are released by the merocrine secretion in domestic fowl (Wight et al. 1971a) or apocrine type of secretion in other avian species (Sakai 1981). Brobby (1972) and Sakai (1981) reported that HG was composed of many lobules arranged around a central channel and that each lobule contained central lumen and corpus. The glands in this study were multilobular, compound tubulo-alveolar, and the secretion mode was apocrine.

Brobby (1972) reported that the HG was enveloped by a connective tissue capsule. This capsule contained, apart from compact collagenous fibres, isolated smooth muscle cells, nerves, and blood vessels in domestic ducks. In the present study of domestic geese the HG was enveloped by a thin connective tissue capsule. Brobby (1972) reported that HG of domestic ducks was divided into lobules, which appeared as polygonal zones of varying size with a central canal. The lobules are separated by a thin strand of connective tissue. We observed that septa from the connective tissue capsule penetrated into the gland dividing it into lobes and lobules of varying size. Liman and Gülmez (1996) reported that the volume and size of the organ increased, and the capsule and septa between lobules thickened on the $21^{\text {st }}$ day after hatching in domestic geese.

In this study, it was observed that glandular units were elongated and protruded as folds into the large lumen of the duct.

Brobby (1972) reported that in the domestic duck the tubules are completely lined by a single layer of tall columnar cells staining uniformly. Their large nuclei lay near the base of the cells. The cytoplasm was poorly stained and contained scattered granules. The cell borders were easily resolved. In the present study we observed cellular characteristics of glands similar to that of the domestic duck. With high-resolution there were vesicles within these cells containing the secretory droplets. We observed that the borders of glandular epithelial cells were not evident and their apical cytoplasm was acidic.

A number of researchers (Bloom and Fawcett 1975; Liman and Gülmez 1996) reported that the lacrimal gland and the superficial gland (nicticating) have many ducts, whereas the HG has but one duct (Brobby 1972; Sakai 1981). Burns and Maxwell (1979) reported that HGs of the turkey, duck, and hen have only one duct, and that in each one of these species there are lymphoid nodules near the epithelium of the crypts. Our observations reveal the HG of domestic geese has only one main duct.

Burns and Maxwell (1979) reported that the epithelial cells of the duct in HG varied from cubic to columnar in shape in the turkey, duck and hen, and goblet cells were within the ductal epithelium. Furthermore, they found stratified and pseudo-stratified epithelia regions. In this study, the epithelial cells of these ducts were observed to vary in size and to be stratified. It was observed that the shapes and positions of the cells were changing throughout the duct; those near the basement membrane were polygonal, whereas the ones near the lumen were cuboidal. Goblet cells were distributed between these cells. We conclude that the epithelium is pseudostratified. 
Brobby (1972) reported that the centrally located cells of the HG in domestic ducks were observed to be PAS-positive, and showed a combination of blue (acid mucosubstance) and violet (neutral mucosubstance) in combined AB/PAS technique, and these cells were $\mathrm{AB}$-positive in $\mathrm{AB}(\mathrm{pH}=2.5)$ staining. Liman and Gülmez (1996) reported that the centrally located cells of the HG in geese were observed to be blue (acid mucin) in AB/PAS technique. Sakai (1981) found that the glandular cells in HG were positive in PAS reaction in some avian species. In this study, the more centrally located cells of the HG in domestic geese were observed PAS, $\mathrm{AB}(\mathrm{pH}=2.5)$ and $\mathrm{AB} / \mathrm{PAS}$ positive.

Burns and Maxwell (1979) found that the goblet cells located between the epithelial cells of duct were weakly PAS-positive and weakly $\mathrm{AB}(\mathrm{pH} 1$ and $\mathrm{pH} 2,5)$ positive and weakly AB/PAS positive in turkey, duck, and aged hens. In this study, these cells were also observed PAS, AB ( $\mathrm{pH} 2,5)$, and AB/PAS positive for domestic geese.

The nature of secretion of $\mathrm{HG}$ of various animals in vertebrate family is different. It was serous or sero-mucous in reptiles (Saint-Girons 1985), mucous in turkey (Maxwell et al. 1986), domestic fowl (Wight et al. 1971b; Maxwell and Burns 1979) and domestic ducks (Brobby 1972; Maxwell and Burns 1979). In this study, it was observed that the secretion in domestic geese is mucous.

Previous studies reported the HG contained myoepithelial cells, interposed between the basal surface of the epithelium and the basement membrane, in domestic birds (Rothwell et al. 1972), turkey (Maxwell et al. 1986), camel (Abou-Elmagd 1992), hamster (Lopez et al. 1992), gecko (Baccari et al. 2000), Dhub lizard (Sabry and Al-Ghaith 2000), tree shrew (Pradidarcheep et al. 2003), ostrich (Altunay and Kozlu 2004), South American armadillo (Marcos and Affanni 2005), and Atlantic bottlenose dolphin (Ortiz et al. 2007). The HG of domestic geese, investigated in this study, contained also myoepithelial cells.

The HGs of many species contain abundant immunocompetent cells. These are chiefly plasma cells (Bang and Bang 1968; Aitken and Survashe 1977; Schramm 1980; Sakai 1981; Scott et al. 1993; Yasmina 1994; Marcos and Affanni 2005; Khan et al. 2007). Rothwell et al. (1972) found that the plasma cells in fowl were similar to that in mammals in terms of ultrastructure and that they had common histological characteristics. We also observed plasma cells in the capsule and septa in domestic geese.

The lipid composition of the HG has been positively stained with Sudan black in rabbits (Kasama et al. 1973; Rock and Snyder 1975; Rock et al. 1976), rats (Murawski and Jost 1974; Zackor and Murawski 1976), golden hamster (Lopez et al. 1993), mice (Watanabe 1980), and guinea pigs (Yamazaki et al. 1981). However, Sudan black revealed no lipid composition of the HG in ducks (Ballantyne and Fourman 1967), chickens, turkeys, pheasants, and the cardinal (Paule 1957; Sakai 1981). The HG of domestic geese, in this study, was also Sudan black-negative.

As a result of all these histological and histochemical analysis, it was found that the HG of domestic geese was covered by a capsule, which divides the organ into lobes and lobules. The glands were multilobular, compound tubulo-alveolar. Furthermore, the organ had a single duct, the secretion was mucous, and the secretion mode was apocrine.

\section{Histologická studie Harderovy žlázy u husy domácí (Anser anser domesticus)}

Cílem této práce bylo prostudovat a popsat morfologickou stavbu Harderovy slzné žlázy u husy domácí. Vzorky tkáně byly získány od dospělých samců $(\mathrm{n}=9)$ a samic $(\mathrm{n}=9)$ husy domácí a byly zpracovány pro použití světelné mikroskopie. Tkáňové řezy byly barveny Malloryho trichromem, dále byla použita impregnace stř́ibrem, methylová zeleňpyronin, Schiffovo činidlo ( $\mathrm{pH}$ 2.5), alciánová modř a Sudan B. Struktura Harderovy slzné žlázy u husy domácí je laločnatá, žláza je na povrchu krytá obalem, který vysílá do jejího 
nitra trabekuly, dělící orgán na laloky a lalůčky. Žlázový epitel byl multilobulární, smíšený tubuloalveolární. Sekret Harderovy žlázy byl mucinózní a sekreční typ žlázy apokrinní; žláza uvolňuje sekret na vnitřní povrch mžurky jedním vývodem.

\section{References}

Abou-Elmagd A 1992: Ultrastructural observations on myoepithelial cells and nerve terminals in the camel Harderian gland. Anat Embryol 185: 501-507

Aitken ID, Survashe B 1977: Plasma cells in vertebrate paraocular glands. Int Arch Allergy Appl Immunol 53: 2-67

Altunay H, Kozlu T 2004: The fine structure of the Harderian gland in the Ostrich (Struthio camelus). Anat Embryol 33:141-145

Baba T, Kawata T, Masumoto K, Kajikawa T 1990: Role of the Harderian gland in immunoglobulin. A production in chicken lacrimal fluid. Res Vet Sci 49: 20-24

Baccari GC, Chieffi G, Matteo LD, Dafnis D, Rienzo GD, Minucci S 2000: Morphology of the Harderian gland of the Gecko, Tarentola mauritanica. J Morphol 244: 137-142

Ballantyne B, Fourman J 1967: The histology and histochemistry of the Harderian gland of the domestic duck. J Anat 101:194-199

Bang BG, Bang FB 1968: Localized lymphoid tissues and plasma cells in paraocular and paranasal organ systems in chickens. Am J Pathol 53: 735-751

Bloom W, Fawcett DW 1975: A textbook of histology. $10^{\text {th }}$ ed. W. B. Saunders, Philadelphia.

Brobby GW Sr 1972: Harderian gland of domestic duck (Anas platyrhynchos). Morphological and histochemical investigations. Z Zellforsch Mikrosk Anat 133: 223-230

Burns RB, Maxwell MH 1979: The structure of the Harderian and lacrimal gland ducts of the turkey, fowl and duck. A light microscope study. J Anat 128: 285-292

Culling CFA, Allison RT, Barr WT 1985: Cellular pathology technique. $4^{\text {th }}$ ed. Butterworths, London, 642 p.

Kasama K, Rainley WT, Snyder F 1973: Chemical identification and enzymatic synthesis of a newly discovered lipid class-hydroxyalkylglycerols. Arch Biochem Biophys 154: 648-658

Khan MZI, Jahan MR, Islam MN, Haque Z, Islam MR, Kon Y, 2007: Immunoglobulin (Ig)-containing plasma cells in the Harderian gland in broiler and native chickens of Bangladesh. Tissue Cell 39: 141-149

Liman N, Gülmez N 1996: The light microscopic examinations on the development of the Harderian gland of the Geese (Anser anser). Ankara Univ Vet Fak Derg 43: 25-30

Lopez JM, Tolivia J, Alvarez-Uria M 1992: An ultrastructural study of myoepithelium maturation during postnatal development of the hamster Harderian gland. Anat Embryol 186: 573-582

Lopez JM, Tolivia J, Alvarez-Uria M, Payne AP, McGadey J, Moore MR 1993: An electron microscopic study of the Harderian gland of the Syrian hamster with particular reference to the process of formation and discharge of the secretory vacuoles. Anat Rec 235: $342-352$

Marcos HJA, Affanni JM 2005: Anatomy, histology, histochemistry and fine structure of the Harderian gland in the South American armadillo Chaetophractus villosus (Xenarthra, Mammalia). Anat Embryol 209: 409-424

Maxwell MH, Burns RB 1979: The ultrastructure of the epithelium of the ducts of the Harderian and lacrimal glands of the turkey, fowl and duck. J Anat 128: 445-459

Maxwell MH, Rothwell B, Burns RB 1986: A fine structural of the turkey Harderian gland. J Anat 148: 147-157

Munkeby BH, Smith HJ, Larssen EHW, Bjornerud A, Bjerkas I 2006: Magnetic resonance imaging of the Harderian gland in piglets. J Anat 209: 699-705

Murawski U, Jost U 1974: Unsaturated wax esters in the Harderian gland of the rat. Chem Phys Lipids 13:155-158

Norwell JE, Clabough JW 1972: Adrenergic and cholinergic innervations of the hamster Harderian gland. Science 178: $1102-1103$

Olcese J, Wesche A 1989: The Harderian gland. Comp Biochem Physiol A-Comp Physiol 93: 655-665

Ortiz GG, Feria-Velasco A, Tarpley RL, Bitzer-Quintero OK, Rosales-Corral SA, Velazquez-Brizuela IE, LopezNavarro OG, Reiter RJ 2007: The orbital Harderian gland of the male Atlantic Bottlenose Dolphin (Tursiops truncates): A morphological study. Anat Histol Embryol 36: 209-214

Ohshima K, Hiramatsu K 2002: Immunohistochemical localization of three different immunoglobulin classes in the Harderian gland of young chicken. Tissue Cell 34: 129-133

Paule WJ 1957: The comparative histochemistry of the Harderian gland. Dissertation. Ohio State University, Columbus, Ohio

Payne AP 1994: The Harderian gland: a tercentennial review. J Anat 185: 1-49

Pradidarcheep W, Asavapongpatana S, Mingsakul T, Poonkhum R, Nilbu-Nga S, Somana R 2003: Microscopic anatomy of the orbital Harderian gland in the Common Tree Shrew (Tupaia glis). J Morphol 255: 328-336

Rock CO, Snyder F 1975: Metabolic interrelation of hydrxy-substituted ether-linked glycerolipids in the pink portion of the rabbit Harderian gland. Arch Biochem Biophys 171: 631-636

Rock CO, Fitzgerald V, Rainley WT, Snyder F 1976: Mass spectral identification of 2- $(O$-acyl) hydroxy fatty acid esters in the white portion of the rabbit Harderian gland. Chem Phys Lipids 17: 207-212

Rothwell B, Wight PAL, Burns RB, Mackenzie M 1972: The Harderian glands of the domestic fowl. III. Ultrastructure. J Anat 112: 233-250 
Sabry I, Al-Ghaith L 2000: The Harderian gland of the Dhub lizard Uromastyx microlepis of the Kuwaiti desert: an ultrastructural approach. Tissue Cell 32: 71-78

Saint-Girons H 1985: Histology of the orbital glands of crocodilia and testudines in relation to Lepidosauria. Ann Sci Nat Zool Biol Anim 7: 249-264

Sakai T 1981: The mammalian Harderian gland: morphology, biochemistry, function and phylogeny. Arch Histol Jpn 44: 299-333

Sakai T 1992: Comparative anatomy of the mammalian Harderian glands. In: Webb SM, Hoffman RA, PuigDomingo ML, Reiter RJ (Eds): Harderian glands: porphyrin, metabolism, behavioral and endocrine effects. Springer, Berlin, pp. 7-23

Saka T, Yohro T 1981: A histological study of the Harderian gland of Mongolian gerbils. Meriones meridianus. Anat Rec 100: 259-270

Schramm U 1980: Lymphoid cells in the Harderian gland of birds. An electron microscopical study. Cell Tissue Res 205: 85-94

Schwarz-Karsten H 1937: Über die orbitaldrüsen von Lacerta agilis, Lacerta muralis, Ophisops elegant, Tarentola mauretanica und Tropidonotus natrix. Morphol Jahrb 80: 248-279

Scott TR, Savage ML, Olah I 1993: Plasma cells of the chickens Harderian gland. Poult Sci 72: 1273-1279

Watanabe M 1980: An autoradiographic biochemical and morphological study of the Harderian gland of mouse. J Morphol 163: 349-365

Wight PAL, Burns RB, Rothwell B, Mackenzie GM 1971a: The Harderian gland of the domestic fowl. I. Histology with reference to the genesis of plasma cells and Russell bodies. J Anat 100: 307-315

Wight PAL, Mackenzie G, Rothwell B, Burns RB 1971b: The Harderian glands of the domestic fowl. II. Histochemistry. J Anat 110: 323-333

Woodhouse MA, Rhodin JAG 1963: The ultrastructure of the Harderian gland of the mouse with particular reference to the formation of its secretory product. J Ultrastruct Res 9: 76-98

Yamazaki T, Seyama Y, Otsuka H, Ogawa H, Yamakawa T 1981: Identification of alkyl-diacylglycerols containing saturated methyl branched chains in the Harderian gland of guinea pig. J Biochem 89: 683-691

Yasmina D 1994: the Harderian gland and its excretory duct in the Wistar rat. A histological and ultrastructural study. J Anat 184: 553-56

Zackor JHE, Murawski U 1976: 1-Alkyl-2,3-diacylglycerin in der Harderschen Drüse der Ratte. Hoppe-Seyler's Z Physiol Chem 357: 288-28 
Plate III

Boydak M. et al.: Histological Studies ... pp. 199-204

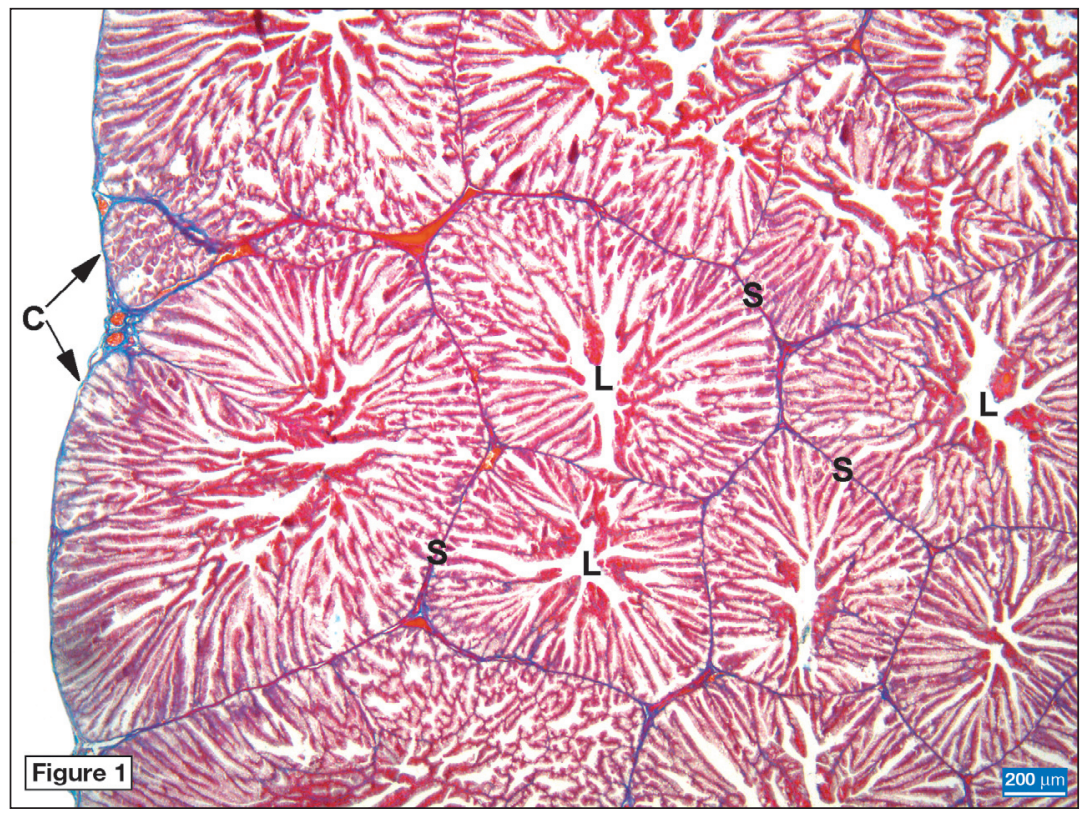

Fig. 1. Lobules constructing the Harderian gland in domestic geese and the corpus glandules in the lobules. Capsule (C), Septa (S), Lumen (L). Trichrome staining, bar: $200 \mu \mathrm{m}$.

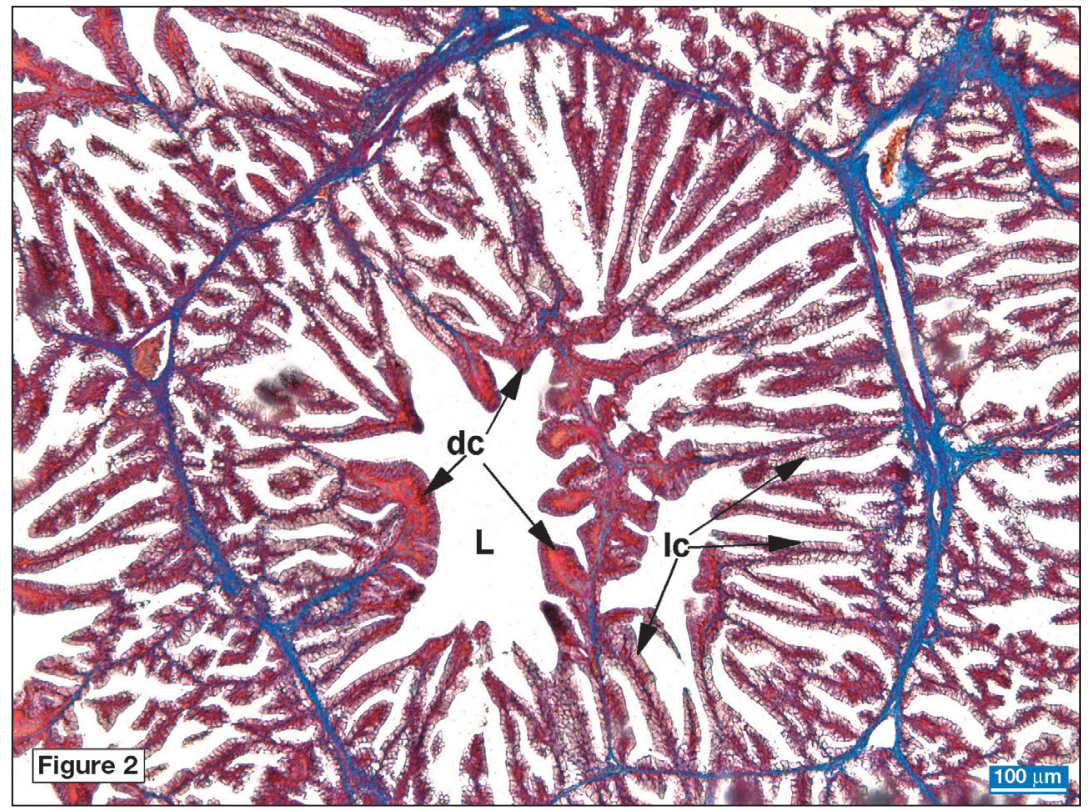

Fig. 2. Light cells (lc) in the collum part and dark cells (dc) in the apex part of corpus glandules inside the lobule of Harderian gland in domestic geese. Lumen (L). Trichrome staining, bar: $100 \mu \mathrm{m}$. 


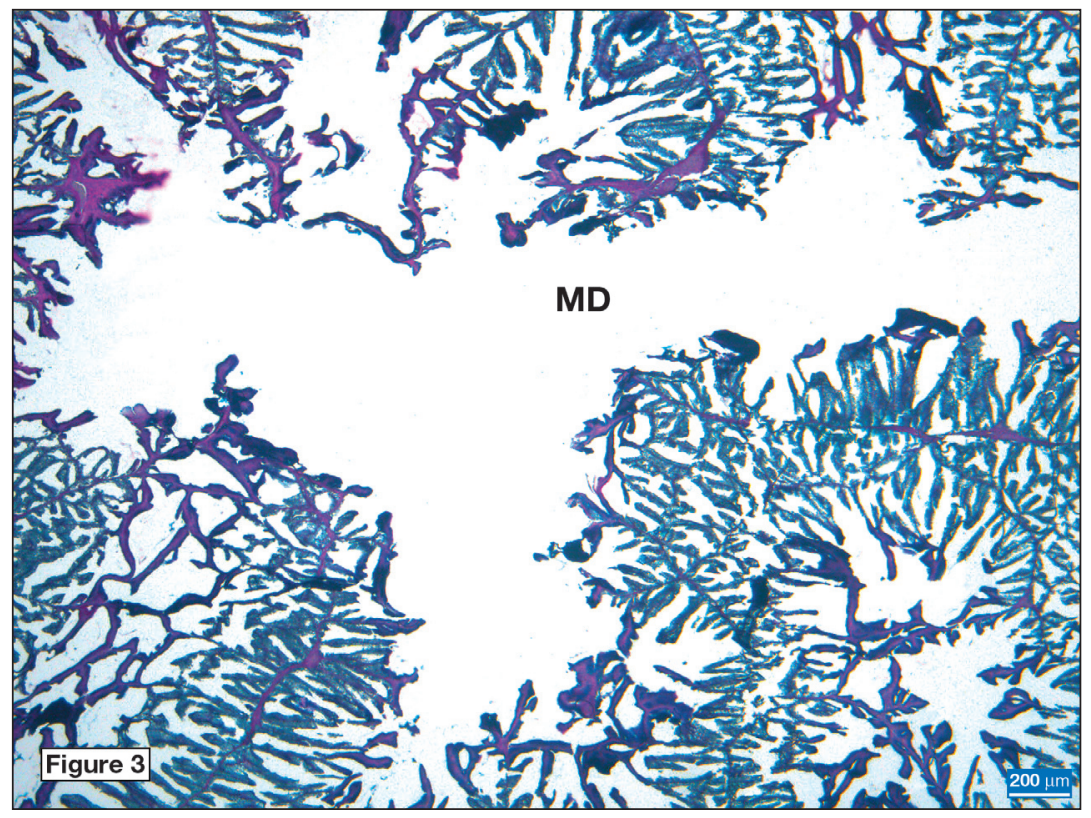

Fig. 3. The main duct (MD) located between the lobules of the HG in domestic geese. Trichrome staining, bar: $200 \mu \mathrm{m}$.

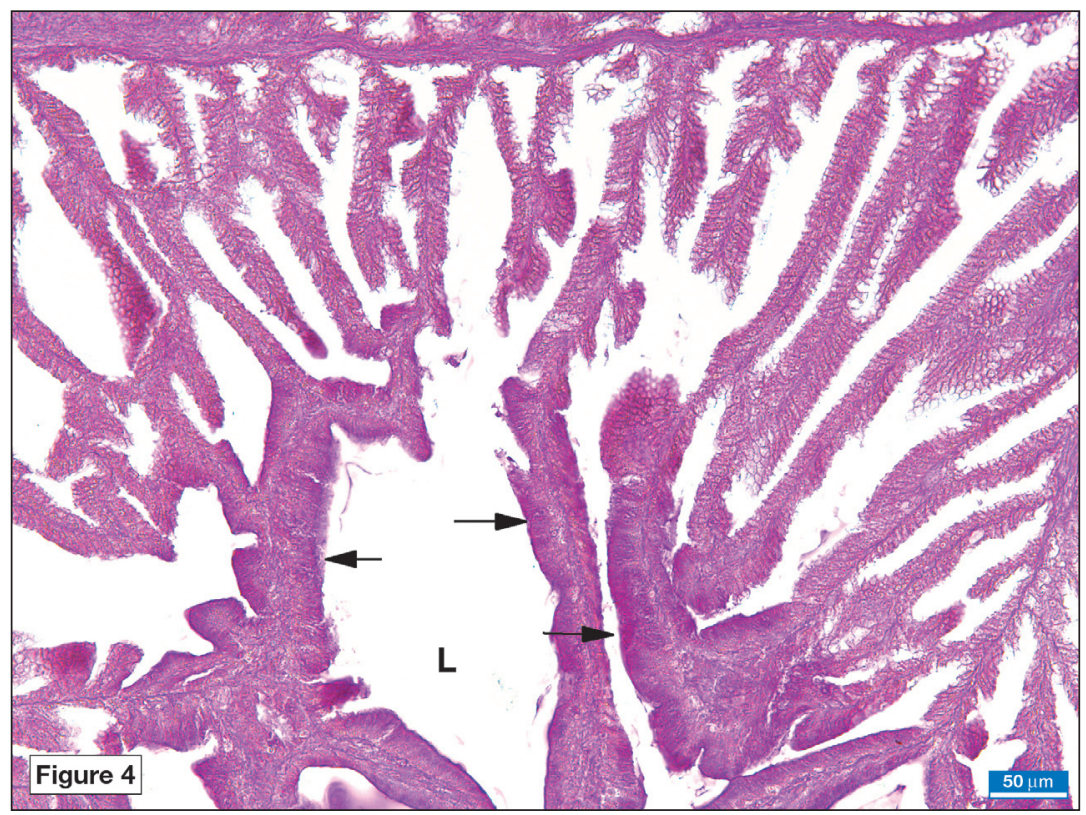

Fig. 4. PAS-positive epithelial cells (arrows) located in the apex of corpus glandules of the HG in domestic geese. PAS reaction, bar: $50 \mu \mathrm{m}$. 


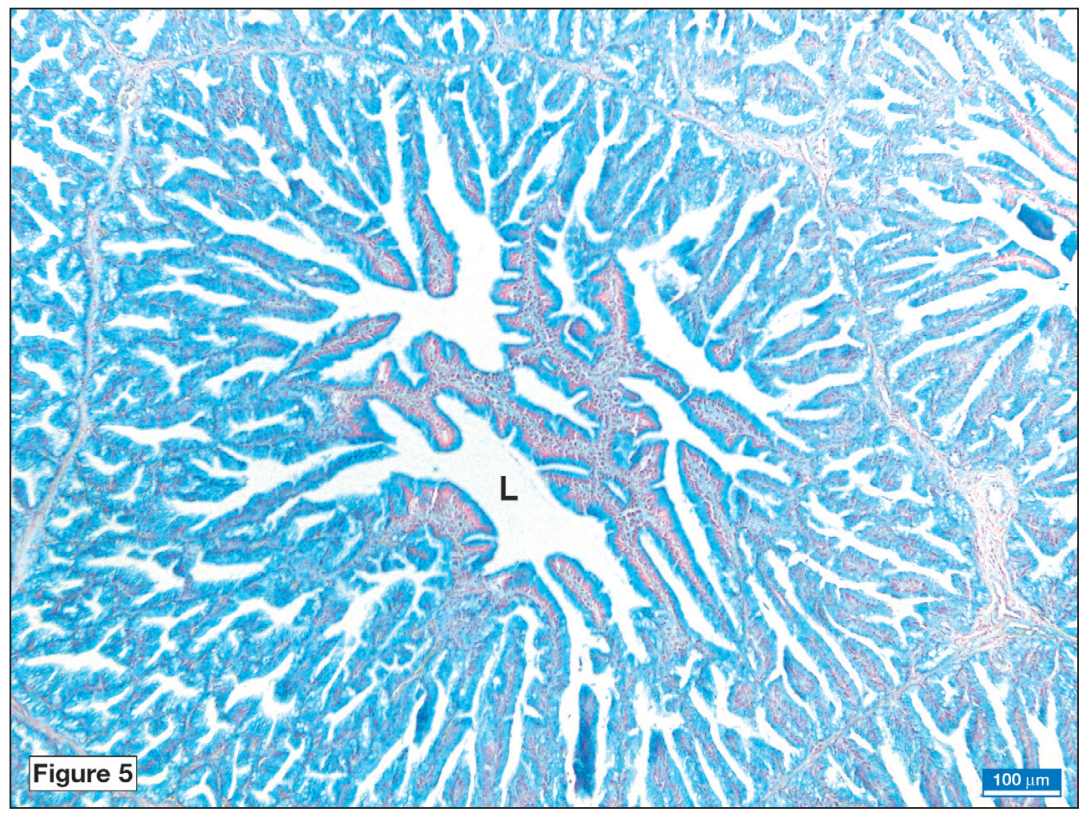

Fig. 5. AB-positive epithelial cells located in the glandular units of the HG in domestic geese. Lumen (L). Alcian Blue (AB) staining, bar: $100 \mu \mathrm{m}$.

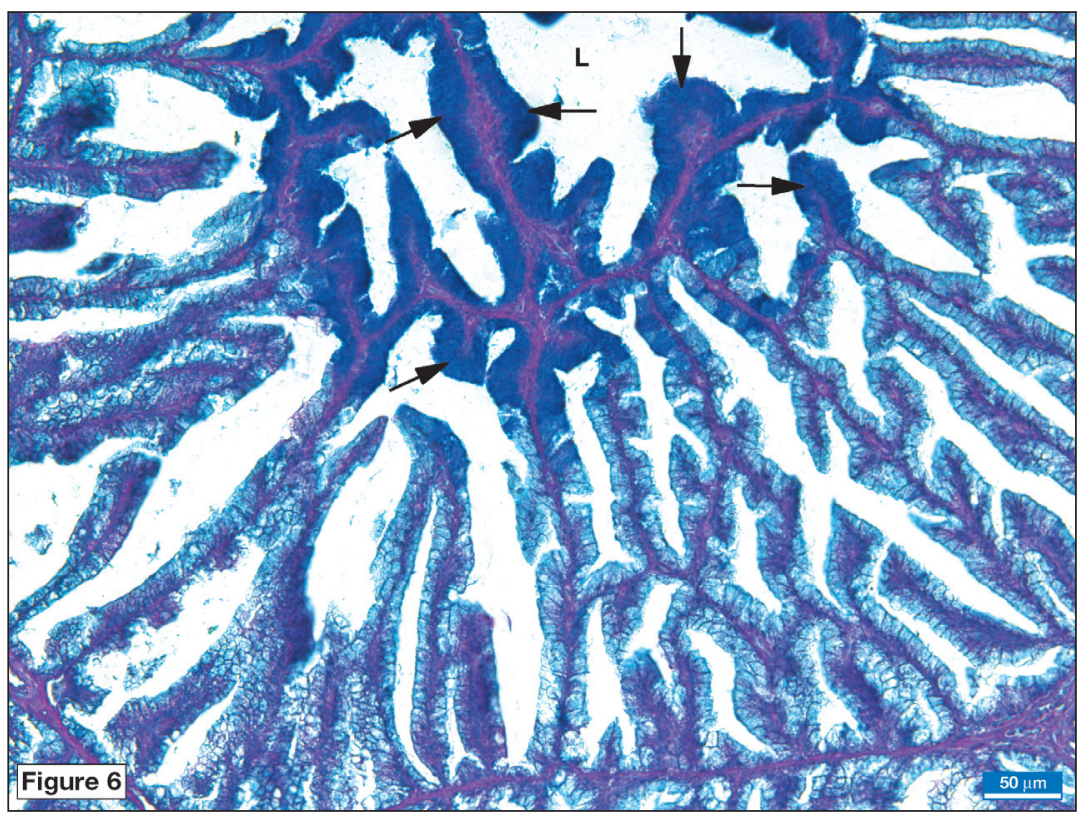

Fig. 6. AB/PAS-positive and weak AB/PAS-positive epithelial cells (arrows) located in the apex of corpus glandulae of the HG in domestic geese. AB/PAS combine staining, bar: $50 \mu \mathrm{m}$. 


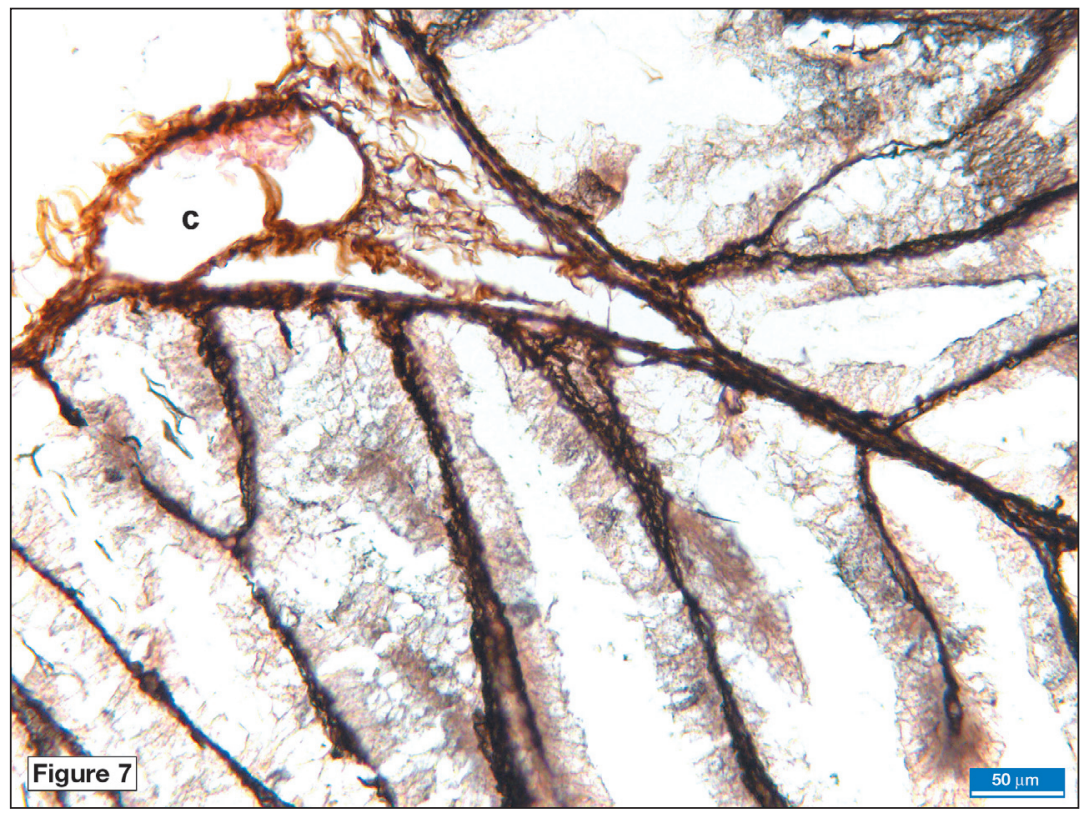

Fig. 7. Reticular fibre networks in the glandular units of the HG in domestic geese. Capillary (c). Silver impregnation, bar: $30 \mu \mathrm{m}$.

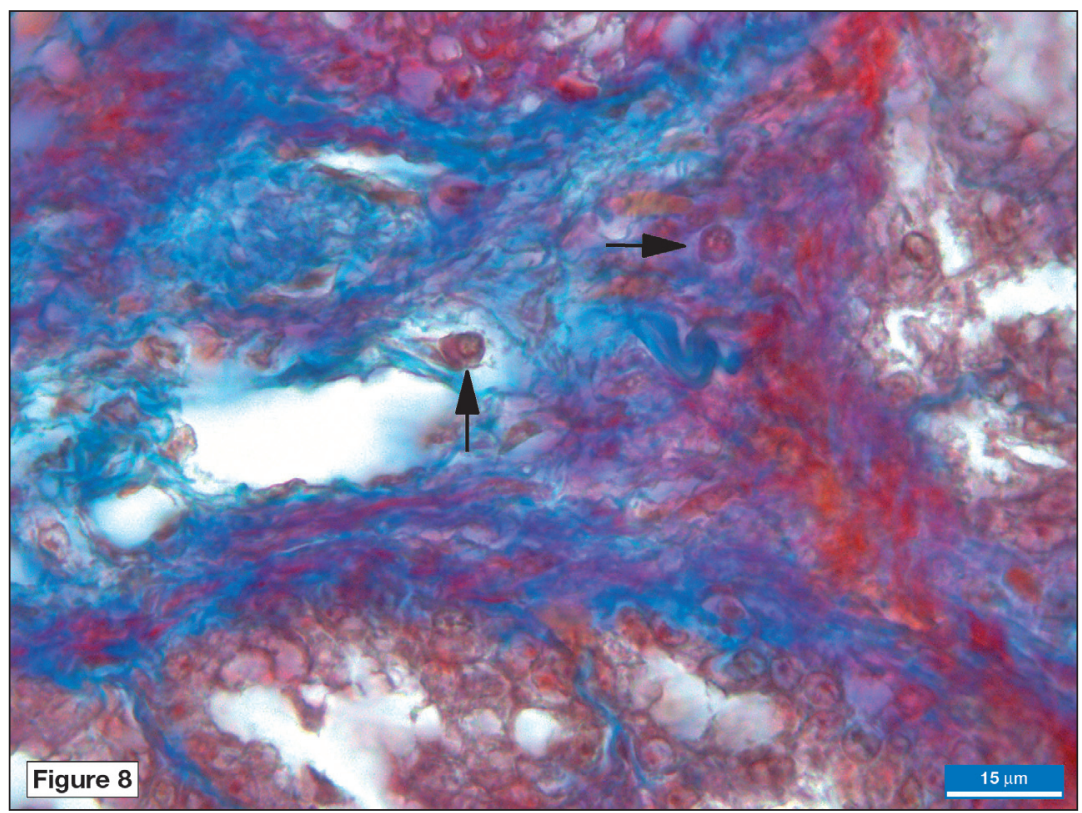

Fig. 8. The plasma cells (arrows) in septa of Harderian gland in domestic geese. Trichrome staining, bar: $15 \mu \mathrm{m}$. 